\title{
Potential Impact of MicroRNA Gene Polymorphisms in the Pathogenesis of Diabetes and Atherosclerotic Cardiovascular Disease
}

\author{
Imadeldin Elfaki ${ }^{1, *}$, Rashid Mir ${ }^{2}$, Mohammad Muzaffar Mir ${ }^{3}{ }^{-}$, Faisel M AbuDuhier ${ }^{2}$, \\ Abdullatif Taha Babakr ${ }^{4}$ and Jameel Barnawi ${ }^{2}$ \\ 1 Department of Biochemistry, Faculty of Science, University of Tabuk, Tabuk 71491, Saudi Arabia \\ 2 Department of Medical Lab Technology, Prince Fahd Bin Sultan Research chair, Faculty of Applied Medical \\ Sciences, University of Tabuk, Tabuk 71491, Saudi Arabia; rashid@ut.edu.sa (R.M.); \\ fabu-duhier@ut.edu.sa (F.M.A.); jbarnawi@ut.edu.sa (J.B.) \\ 3 Department of Basic Medical Sciences, College of Medicine, University of Bisha, Bisha 61992, Saudi Arabia; \\ mirmuzaffar11@gmail.com \\ 4 Department of Medical Biochemistry, Faculty of Medicine, Umm Al-Qura University, Makkah 57039, \\ Saudi Arabia; abdullatiftaha@hotmail.com \\ * Correspondence: ielfaki@ut.edu.sa; Tel.: +966-50-639-4882
}

Received: 2 October 2019; Accepted: 12 November 2019; Published: 25 November 2019

\begin{abstract}
MicroRNAs (miRNAs) are endogenous, small (18-23 nucleotides), non-coding RNA molecules. They regulate the posttranscriptional expression of their target genes. MiRNAs control vital physiological processes such as metabolism, development, differentiation, cell cycle and apoptosis. The control of the gene expression by miRNAs requires efficient binding between the miRNA and their target mRNAs. Genome-wide association studies (GWASs) have suggested the association of single-nucleotide polymorphisms (SNPs) with certain diseases in various populations. Gene polymorphisms of miRNA target sites have been implicated in diseases such as cancers, diabetes, cardiovascular and Parkinson's disease. Likewise, gene polymorphisms of miRNAs have been reported to be associated with diseases. In this review, we discuss the SNPs in miRNA genes that have been associated with diabetes and atherosclerotic cardiovascular disease in different populations. We also discuss briefly the potential underlining mechanisms through which these SNPs increase the risk of developing these diseases.
\end{abstract}

Keywords: diabetes mellitus; cardiovascular disease; atherosclerosis; MicroRNA; single nucleotide polymorphisms (snps)

\section{Introduction}

Micro RNAs (miRNAs) are short 22 24 nucleotides in length, single-stranded and non-coding RNA molecules that regulate post-transcriptional gene expression [1]. The discovery of the miRNAs has opened a new era in genome biology. They regulate gene expression by binding to the $3^{\prime}$ untranslated regions ( $\left.3^{\prime} \mathrm{UTRs}\right)$ of their target mRNAs and thereby inhibit the translation [2]. There are three steps for canonical miRNA biogenesis in animals [3]. Firstly, it is transcribed by RNA polymerase II to a primary miRNA (pri-miRNA) that is about 100 nucleotides in length and has the structure of a stem-loop that fold back [4]. Secondly, in the nucleus, the pri-miRNA is processed into a precursor (pre-miRNA of about 60-70 nucleotides) by the nuclear RNase III Drosha and the RNA-binding protein DCGR8 [5]. Finally, the pre-miRNA is exported to the cytoplasm by exportin 5 where the mature 22nucleotides miRNA is produced when pre-miRNA is cleaved by the cytoplasmic RNase III Dicer-TRBP (transactivation-response RNA binding protein) complexes [3,6-8]. The miRNAs inhibit or silence the 
mRNA translation by forming a ribonucleoprotein complex, called RNA-induced silencing complex (RISC) $[9,10]$. The mature miRNA then complexes with Argonaute proteins and form the RNA-induced silencing complex (RISC) [10]. In the non-canonical pathway, other enzymes than Drosha-DGCR8 and Dicer-TRBP are used as RNAses [3]. For instance, in the mirtron pathway, short hairpin introns are excised by splicing and lariat-debranching enzyme to generate intermediates of the RNA interference effectors or miRNAs [11]. MiRNAs can also be produced by other RNases from certain hairpin of non-coding species of RNA, for example, the transfer RNAs of small nucleolar RNAs [12,13]. The translation inhibition of the target mRNAs occurs by binding of the miRNA within the RISC to the complementary sequences in the $3^{\prime}$ UTRs of target mRNAs (Figure 1) [10]. Then, there are two types of translation inhibition, the mRNA deadenylation and decay (degradation) or translation repression [9]. MicroRNAs are negative regulators of gene expression acting on the mRNA at the post-transcriptional levels [14]. They have been implicated in many various physiological processes such as development, metabolism, differentiation, proliferation, and responses to stress $[9,15]$. It has been estimated that more than 2000 miRNAs have been discovered, and these miRNAs regulate about $30 \%$ of human protein-coding genes $[16,17]$. A single gene may be regulated by many miRNAs. Whereas, a single miRNA may regulate many target genes [18]. Single-nucleotide polymorphisms (SNPs) are present in the genome at a frequency of $1 \mathrm{in} 1 \mathrm{kbp}$ [19]. They are probably the cause of interindividual variations in a physiological trait such as curly hair [19], height and weight [20]. The SNPs can also be the cause of variation in drug response between individuals [21]. Moreover, they can be the cause of several pathophysiological disorders such as diabetes [22-25] cancers or atherosclerosis [21,26-31], obesity, hypertension, psychiatric disorders [20], inflammatory and autoimmune diseases [32]. SNPs at the miRNA gene may enhance, reduce expression, change maturation of miRNA, or disrupt miRNA-mRNA binding [33]. Disruption of miRNA-mRNA binding may contribute to the development of different types of human diseases. This disruption may result from gene polymorphism at the miRNA target site [34-36], or polymorphism in miRNA genes [27,29,30,37-41].

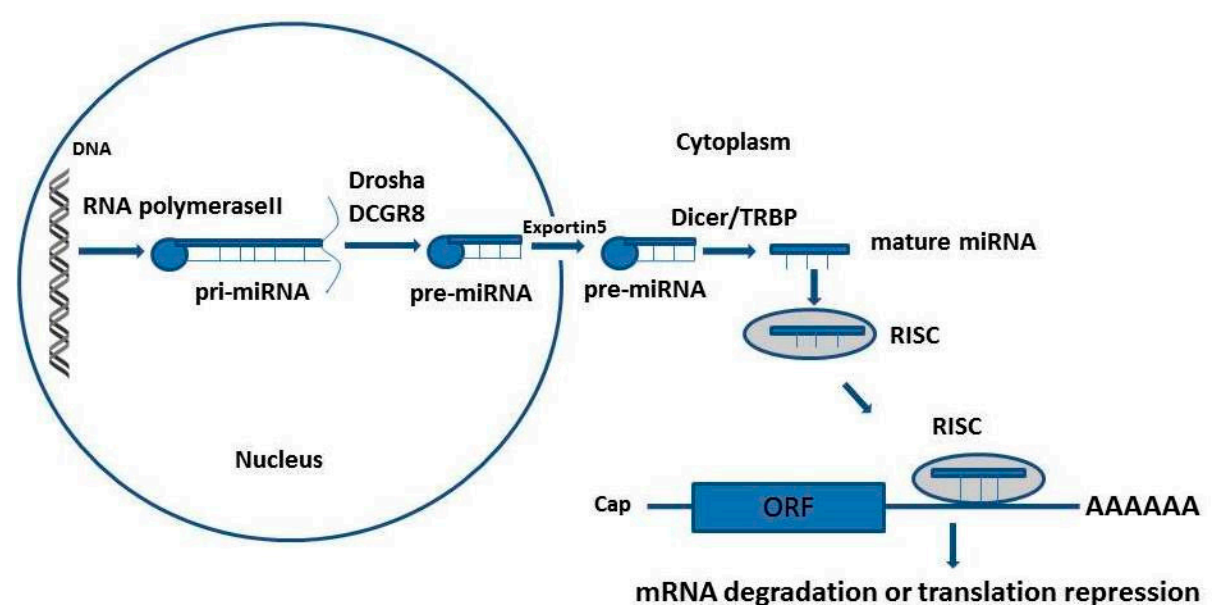

Figure 1. The canonical pathway of miRNA biogenesis in animal cells. This figure is modified from Yu et al., and Graves and Zeng, $2012[3,8]$.

Some microRNAs are implicated in insulin secretion (such as miR-7 and miR-206) [42], and others in the development of pancreatic beta cells such as miR-375 and miR-124a [43,44]. Type 1 diabetes mellitus (T1DM) resulted from the destruction of pancreatic beta cells and lack of insulin [45]. Type 2 diabetes mellitus (T2DM) results from insulin resistance initiated in hepatocytes, skeletal muscles and adipose tissues [45]. Consequently, there is a higher demand for insulin, and beta cells then compensate by increasing insulin secretion until they get exhausted [46]. In fact, loss of function of beta cells (by insults such as inflammation and insulin resistance) is a basic cause of T1DM or T2DM [46]. 
MiRNAs play very important roles in glucose and fat metabolism. There is a different expression of some microRNAs between T2DM cases and controls in skeletal muscles such as miR-29 [47], in adipose tissues such as miR-21 [48], or in pancreatic islets such as MiR-375 [42].

Moreover, miRNAs have been implicated in key processes involved in the pathogenesis of cardiovascular disease (CVD) [10]. For example, they have been reported to be involved in cardiac development such as miR-208, miR-1, miR-133, miR-21 [49]. In addition, the cholesterol homeostasis has been reported to be regulated by the miR-10b, miR-33a/b, miR-106b, and others [10]. While, the miR-1, miR126-5p, miR-155, miR-218 and others involved in the regulation of endothelial cell homeostasis $[10,50]$, and miR-9, miR-21, and others regulate the inflammatory response, for example, miR-21 and miR-26b) [10,51,52].

The roles of SNPs in microRNA target sites in disease pathogenesis have previously been reviewed $[35,53]$. In this review, we discuss the role of SNPs in pri-miRNA, pre-miRNA or mature miRNA sequences in the pathogenesis of diabetes and atherosclerosis-related cardiovascular disease.

\section{Micro-RNA Gene Polymorphisms in Diabetes and Diabetes Complications}

\section{1. $M i R-124 a$ rs531564 G>C}

The miR-124a is expressed in brain and pancreatic tissue [44]. The rs531564 (G Allele) of miR-124a has been associated with T2DM in Han Chinese and Italian populations [54,55]. MiR-124a is involved in pancreatic beta cells differentiation and proliferation as well as insulin secretion [44]. Moreover, the myotrophin gene is a target of miR-124a [44]. The myotrophin gene encodes a cytoplasmic protein that induces exocytosis and hormone secretion [44]. Moreover, miR-124a targets genes that are implicated in the function of the pancreatic beta cells such as Mtpn, Foxa2, Flot2, Akt3, NeuroD1 and Sirt1 [56]. Dysregulation of miR-124a would negatively affect insulin production and secretion [57]. It has also been reported that altered expression of miR-124a may lead to impaired beta cells function through miR-124a effects on its target genes that are involved in beta cell physiology [56].

\section{2. $M i R-375$}

MiR-375 is also expressed in the brain and pancreas and is regulated by transcription factors such as the neurogenic differentiation factor 1 and $\mathrm{Pdx}-1$ which are both important for the development of pancreatic beta cells [44]. MiR-375 also regulates insulin secretion [43]. In addition, miR-375 has been shown to be significantly overexpressed in streptozotocin (STZ)-treated mice and non-obese diabetic mice before the onset of hyperglycemia [58]. Moreover, miR-375 has also significantly increased in STZ and cytokine-induced cell death in isolated mouse islets [58]. MiR-375 levels have decreased after the addition of an inhibitor of cell death [58]. Therefore, it is suggested that the circulating miR-375 levels can be used as a biomarker of beta cells destruction and a potential predictor of diabetes mellitus (DM) [58]. In fact, miR-375 has overlapping functions with miR-124a with respect to pancreatic beta cells development and insulin secretion [44]. However, to our knowledge, the role of miR-375 polymorphisms (e.g., rs1005317333, rs1003868351, rs1001341512, rs1003080648) in the induction of T2DM is yet to be elucidated.

\section{3. $M i R-146 a$ rs $2910164 C>G$}

The rs2910164 has been reported to increase the risk to T2DM in Chinese population [54]. The rs2910164 have been reported to reduce the expression of pre- and mature miR-146a [59]. It has been shown that miR-146a attenuates the activity of NF-kappa B [60], and it has been reported that the activation of the NF-kappa B (and the inflammatory events in general) is an important factor in the pathophysiology and complications of diabetes [61-63]. In contrast to miR-34a (discussed below), increased levels of miR-146 do not influence the capacity of beta cells for insulin secretion, but rather increased beta cells' apoptosis [64]. In a study conducted in the Caucasian population, Kaidonis et al., reported that rs2910164 is associated with diabetic nephropathy in T1DM patients 
and diabetic macular edema in T2DM patients [65]. The rs2910164 SNP is found within the seed sequence of the pre-miR-146a [66]. However, in our predicted structure, the rs2910164 SNP seems to be within the stem-loop of miR-146 (Figure 2E). It is suggested that the C allele of the rs2910164 would reduce the mature miR146a levels [65]. Reduced levels of mature miR-146a would lead to dysregulation of NF-kappa B-mediated inflammation which is implicated in the development of diabetes complications [65]. Ciccacci et al. also reported that the rs2910164 is associated with increased risk to diabetic polyneuropathy (DPN) in the Italian population [67], however, the C allele has a protective effect [67]. Furthermore, miR-146a rs2910164 has been reported to be associated with Preeclampsia in Gestational Diabetes in the Egyptian population [68]. It is suggested that the expression of miR-146a is correlated with the levels of plasma renalase enzyme that maintains renal blood pressure [68-70].

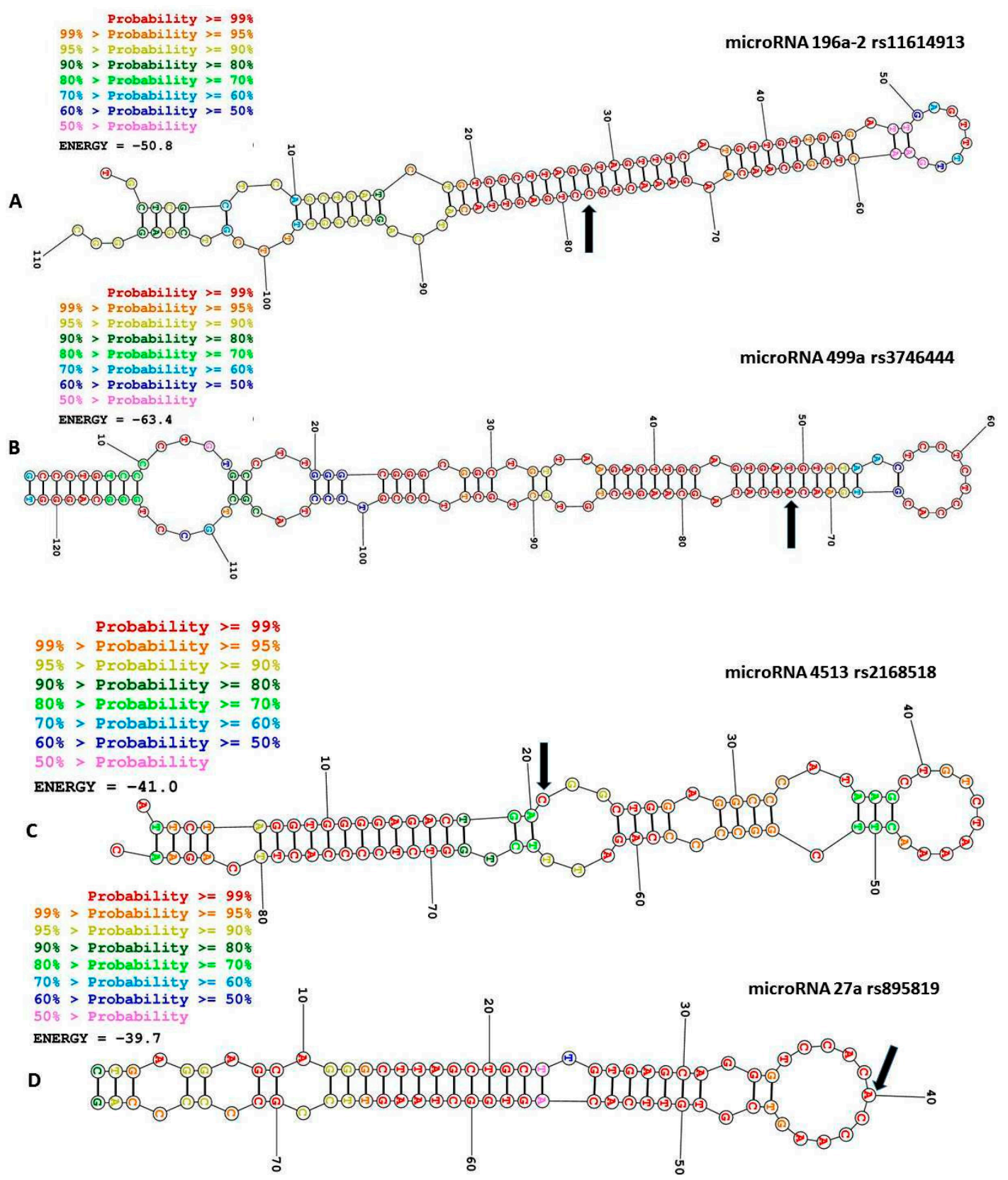

Figure 2. Cont. 


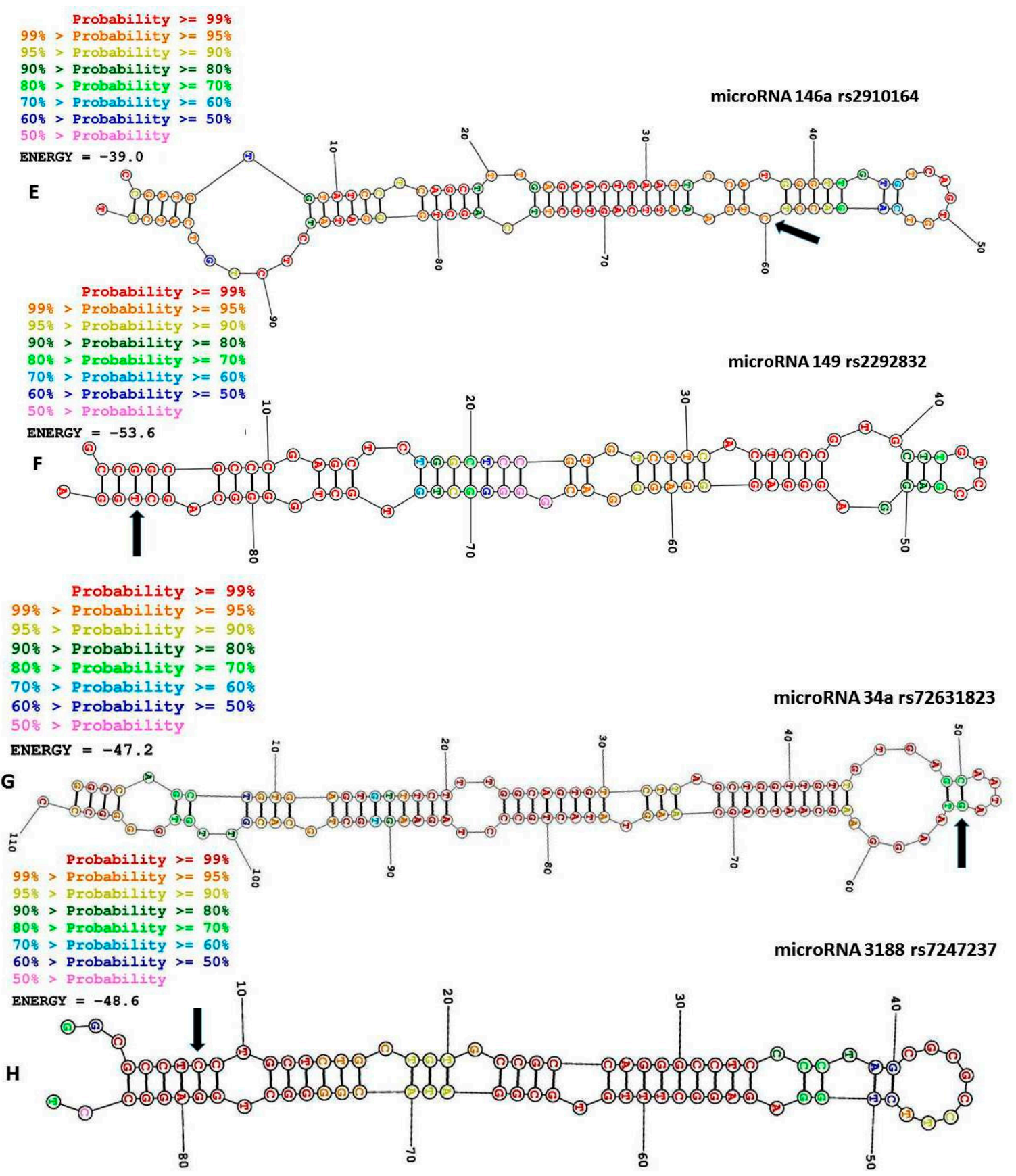

Figure 2. Structural predictions of the microRNAs. The sites of single-nucleotide polymorphisms (SNPs) in the predicted microRNA structures are indicated with arrows. (A) miR-196a2 (rs11614913) 78T $>$ C, probably a stemp-loop SNP (B) miR-499 (rs3746444) 73A > G, probably a stemp-loop SNP (C) MIR-4513 (rs2168518) 21C > T probably a stemp-loop SNP (D) pre-miR-27a (rs895819) 40A $>$ T, probably a stemp-loop SNP (E) miR-146a (rs2910164) 60G>C, probably a stemp-loop SNP (F) miR149 (rs2292832) 86T $>$ C, probably a seed SNP (G) miR34a (rs72631823) 55G >A, probably a stemp-loop SNP (H) miR-3188 (rs7247237) 8C >T probably a seed SNP. The sites of the SNPs are indicated with arrows. This figure has been prepared using the webserver https://rna.urmc.rochester.edu/RNAstructureWeb/. 


\section{4. $M i R-27 a$ rs 895819}

The rs895819 has been reported to be associated with decreased risk to T2DM in Italian and Iranian populations [55,71]. It has been suggested that rs895819T $>C$ increased the expression of the miR-27a [55,71-73]. It has been demonstrated that miR-27 exerts a negative effect on adipogenesis [74]. It has been suggested that miR-27a targets the PPAR gamma and hence negatively influence the differentiation of the adipocyte [75], and the down-regulation of miR-27a would result in dysregulation of adipose tissue and obesity [75]. The role of obesity in the induction of insulin resistance and T2DM is well known [76]. Therefore, wild miR-27a may have a protective role against obesity and hence T2DM. It is conceivable that more active miR-27a (with the CC genotype) has a more protective role against T2DM as reported in previous studies [55,71]. Nevertheless, Wang et al. 2015 have never observed the protecting effect of miR-27 against T2DM in the Chinese Han population [77]. Wang et al., 2015 suggested that this contradiction might be due to the different geographic locations, size of the samples, and ethnicity [77]. The $\mathrm{G}$ allele of miR-27a rs 895819 was associated with increased risk for developing early cardiovascular autonomic neuropathy (CAN) in the Italian population [67].

\subsection{MiR-34a rs72631823 G>A}

The rs72631823 of mi-R34a has been reported to be associated with T2DM [78]. It is located within the terminal loop region of the pre-miRNA of miR-34a [78]. In an experiment conducted in 3 cell lines ( $\beta$-cell line MIN6B1, pancreatic islets and Hela cells) transfected with the miR-34a, it has been shown that the expression of MIR34a has significantly increased with the A allele compared with the wild type ( $\mathrm{G}$ allele). The increased expression of miR-34a bearing the A allele may be due to a more relaxed secondary structure of miR-34a with the A allele than that with the G allele [78], as the more relaxed micro-RNA secondary structure may be processed more sufficiently during biogenesis [78]. MIR34a has been reported to increase beta cells apoptosis and hence DM [78]. Dysfunction of pancreatic beta-cells that induced by the proinflammatory cytokines and palmitate increased the expression levels of miR-34a in $\beta$-cell line MIN6B1, pancreatic islets and islets from diabetic $\mathrm{db} / \mathrm{db}$ mice $[64,78]$. Increased expression levels of miR-34a activate the p53 which leads to increased sensitivity to apoptosis and impaired nutrient-induced secretion of insulin [64]. The impaired insulin secretion is probably because of expression inhibition of the vesicle-associated membrane protein 2 (VAMP-2) [64]. VAMP-2 is a protein expressed in pancreatic beta cells and is critical for calcium-induced insulin exocytosis $[79,80]$. Inhibiting the expression of miR-34a resulted in decreased beta cells apoptosis [64,78,81]. It may be concluded that certain levels of miR-34a expression should be maintained within the pancreatic tissues.

\subsection{MicroRNA Let-7a-2 (MIRLET-7A2 rs1143770)}

The rs1143770 of Let-7 a-2 has been associated with diabetic nephropathy (DN) in the Chinese Han population [82]. Let-7 regulates several aspects of the metabolism of glucose [45]. It has been reported that knockdown of the Let-7 family with an antimiR can be used in anti-diabetic treatment [45]. Overexpression of Let-7 in all organs and in the pancreas, in particular, resulted in impaired glucose tolerance and decreased pancreatic insulin secretion induced by glucose [45]. In addition, knockdown of the Let-7 family with an antimiR treatment resulted in improvement of sensitivity to insulin in muscle cells and hepatocytes of obese mice [45], this treatment resulted in reduced fat mass in muscles as well as in hepatocytes [45]. The rs1143770 C $>\mathrm{T}$ in the regulatory region of Let-7 a-2 (CT/TT genotypes) is associated with increased risk for diabetes and diabetic nephropathy (DN) in the Chinese Han population [82]. It has been suggested that this polymorphism rs $1143770 \mathrm{C}>\mathrm{T}$ causes a partial loss of cyclic adenosine monophosphate response element-binding protein (CREB) [82]. The CREB is a transcription factor implicated in DN [82,83]. 


\section{7. $M i R-155 r s 767649 T>A$}

The TT genotype of rs767649 has been associated with protection against T1DM in the Brazilian population [66]. MiR-155 is overexpressed in immune cells (T, B lymphocytes, macrophages and dendritic cells) [66]. It has been reported that miR-155 is an immune response molecule [84]. For example, it is induced by bacterial lipopolysaccharide (LPS), Interferons- $\beta$, polyriboinosinic-polyribocytidylic acid (poly IC) or Tumor Necrosis Factor- $\alpha$ (TNF- $\alpha$ ) [84]. It has been reported that MIR155 is a transactivational target of nuclear factor kappa B (NF-kappa B) [85], the NF-kappa B upregulates miR-155 [85]. The upregulated miR-155 then, through its targets IKK $\beta$ and IKK $\varepsilon$, leads to the limitation of NF-kappa B [85]. It has been reported that when beta cells exposed to Interleukin-1 (IL-1), the NF-kappa B is activated and translocate to the nucleus. This activation modifies the expression of many genes that cause beta cells' dysfunction and apoptosis [61]. It has been suggested that the A allele of the rs767649 is associated with reduced expression of miR-155 [66]. The reduced expressed miR-155 (with the A allele) would have inefficient control on activated NF-kappa B which predispose to T1DM [66].

\subsection{MiR128a rs11888095 C >T}

The rs 11888095 has been reported to be associated with the development of diabetic polyneuropathy (DPN) in an Italian cohort [67]. Using computational analysis, it is suggested that miR128a targets include genes related to T2DM such as insulin receptor substrate 1 (IRS-1), calpain 10 (CAPN10), and peroxisome proliferator-activated receptor gamma (PPAR gamma) [67]. For example, IRS-1 is an important element in insulin signaling pathway and disturbance of IRS1 complexes may lead to insulin resistance and T2DM [86], while the PPAR gamma is involved in the pathogenesis of various diseases including T2DM [87].

\section{9. $M i R-3188$ rs $7247237 \mathrm{C}>\mathrm{T}$}

The rs7247237 has been reported to be associated with the incidence of vascular complications in T2DM patients from the Chinese population [88]. The rs7247237 SNP (Figure 2H) reduces the expression of mature MiR-3188 [88]. It is suggested that the decreased expression of mature MiR-3188 leads to overexpression of the glutathione S-transferase M1 (GSTM1) and Tribbles pseudokinase 3 (Trib3) [88]. The overexpression of GSTM1 and Trib3 results in reduced Nitric Oxide (NO) production in the endothelial cells through inhibition of endothelial NO synthase [88]. In T2DM, the endothelial dysfunction is caused by reduced bioavailability of endothelial NO synthase [89]. MiR-3188 has been reported to have a role in the regulation of MTOR and PI3K/Akt signaling pathway [90]. Therefore, the MiR-3188 rs7247237 polymorphism (resulting in reduced MiR-3188 expression) may also be involved in the induction of T2DM because impairment of PI3K/AKT signaling pathway results in insulin resistance and T2DM [91].

\subsection{0. $M i R-126$ rs4636297 $A>G$}

The rs4636297 (A-allele) has been reported to be associated with sight threatening diabetic retinopathy (DR) in an Australian cohort with T2DM [92]. It has been reported that miR-126 regulates the amount of circulating vascular endothelial growth factor (VEGF) [92,93]. VEGF is very important for the development and maintenance of the blood and lymphatic vessels [94]. MiR-126 suppresses the inhibitors of the VEGF pathway such as the phosphoinositol-3 kinase regulatory subunit 2 and the Sprouty-related protein SPRED1 [94]. The miR-126 rs4636297 polymorphism has been implicated in the development of ischemic stroke risk in the Chinese population [95]. Thus, miR-126 maintains angiogenesis and integrity of the vascular system [96]. Future research is required to obtain insight into the role of miR-126 rs4636297 polymorphism in the pathogenesis of other diabetic microvascular complications (Table 1). 
Table 1. MicroRNA gene polymorphisms that have been associated with diabetes in different populations.

\begin{tabular}{|c|c|c|c|c|c|}
\hline miRNA & Rs Number & Disease & $\begin{array}{c}\text { No of } \\
\text { Control/Patients }\end{array}$ & Population & Ref \\
\hline \multirow{2}{*}{ 1-MiR-124a } & \multirow{2}{*}{ rs531564 } & T2DM & $610 / 738$ & Chinese & {$[54,55]$} \\
\hline & & T2DM & $185 / 163$ & Italian & \\
\hline \multirow{3}{*}{ 2-MiR-146a } & \multirow{3}{*}{ rs2910164 } & T2DM & $610 / 738$ & Chinese & \multirow{3}{*}[54,65,67]{} \\
\hline & & $\begin{array}{l}\text { T1DM (DN) and } \\
\text { T2DM (DME) }\end{array}$ & $-/ 2948$ & Caucasian & \\
\hline & & T2DM (DPN) & $-/ 132$ & Italian & \\
\hline \multirow{3}{*}{ 3-MiR-27a } & \multirow{3}{*}{ rs895819 } & T2DM & $185 / 163$ & Italian & \multirow{3}{*}[55,71,77]{} \\
\hline & & T2DM & $209 / 204$ & Iranian & \\
\hline & & T2DM & $967 / 995$ & Chinese Han & \\
\hline 4-MiR-34a & rs72631823 & T2DM & - & $\begin{array}{l}\text { INS-1, MIN6 } \\
\text { and Hela cell } \\
\text { lines }\end{array}$ & [78] \\
\hline 5-MIRLET7A2 & rs1143770 & $\mathrm{T} 2 \mathrm{DM} / \mathrm{DN}$ & $62 / 212$ & Chinese & [82] \\
\hline 6-MiR128a & rs11888095 & DPN & $-/ 132$ & Italian & [67] \\
\hline
\end{tabular}

Abbreviations: T1DM: Type 1 diabetes mellitus, T2DM: Type 2 diabetes mellitus, DN: diabetic nephropathy, DPN: diabetic polyneuropathy.

\section{Micro-RNA Gene Polymorphisms in Atherosclerotic Cardiovascular Disease}

\subsection{The miR-196a2 rs11614913 T>C}

The rs11614913 of miR-196a2 (TT genotype) has been shown to be associated with increased risk to CVD in T2DM patients from the Polish population [37]. Recently, Fragoso et al., suggested that the rs11614913 is associated with coronary artery disease (CAD) in the Mexican population [97]. The rs11614913 (Figure 2A) polymorphism of miR-196a2 affects the expression of mature miR-196a2 and its binding to the target mRNAs [98]. The effect of rs11614913 on miR-196a2 may have an impact on the risk and progression of diseases $[99,100]$. This polymorphism affects the miR-196a-HOXB8-Shh signaling pathway, which is critical for cardiac septation, morphogenesis of the outflow tract and valve development [37,49]. Moreover, it has been reported that annexin A1 is regulated by miR-196a [101]. Annexin A1 was reported to attenuate cardiovascular complications in T1DM [102] and plays a protective role against the inflammatory process in atherosclerosis, myocardial infarction and stroke [103]. This protective role may be because annexin A1 reduces TNF-alpha levels [37]. The role of TNF-alpha and inflammatory cytokines in the induction of the inflammatory process (e.g., atherosclerosis) is well established [104]. The miR-196a2 (rs11614913) polymorphism may thus reduce the regulatory capacity of the annexin A1 by miR-196a $[98,100]$.

\section{2. $M i R-499$ rs3746444 $A>G$}

The rs3746444 (GG genotype) which is present in 20 intron of cardiac $\beta$-myosin heavy chain 7B gene of human has been associated with myocardial infarction in Chinese and Egyptian populations [105-107]. MiR-499 (Figure 2B) is present in skeletal muscles, the myocardium and brain [105,108]. MiR-499 enhances the differentiation of myocardial cells [109]. Furthermore, miR-499 has been demonstrated to inhibit the pathway of mitochondrial apoptosis and protects the cardiac cells from injury induced by reactive oxygen species (ROS) [110]. Moreover, it has been reported that miR-499 promotes the recovery of the heart after myocardial infarction (MI) by enhancing the maturation of human cardiac stem cells [111]. Furthermore, targets of miR-499 include the interleukin proteins that are involved in the activation of inflammatory processes [112]. It has been also been reported that both isoforms of the catalytic subunit of calcineurin are targets of MIR499 [113]. Moreover, miR-499 decreases 
the apoptosis in cardiomyocytes by inhibition of dephosphorylation of dynamin-related protein-1 (Drp1) mediated by its direct target calcineurin [113]. Hence, miR-499 reduces the activation of the mitochondrial fission program mediated by Drp1 [113]. The mitochondrial fission is involved in the early stage of apoptosis [114]. Li et al. 2015 [105] concluded that the rs3746444 polymorphism induces CAD risk in 2 ways. Firstly, it disturbs miR-499 regulation of blood pressure; secondly, it hampers miR-499 anti-apoptotic effect in cardiomyocytes [105]. In a recent study by Li et al., it has been reported that the $G$ allele of the rs 3746444 is associated with ischemic stroke in the Chinese population [115]. Li et al., suggested that the association of rs3746444 with ischemic stroke because miR-499 has roles in the reduction of the activation of the mitochondrial fission program mediated by Drp1 [115], as well as it has roles in the regulation of expression of inflammatory cytokines such as C-reactive protein and interleukins [115]. The role of inflammatory cytokines in cardiovascular disease is well established [116]. MiR-499 polymorphism (rs3746444) has also been reported to be associated with cancers [117] and autoimmune diseases [118].

\section{3. $M i R-4513 r s 2168518 \mathrm{C}>\mathrm{T}$}

The rs2168518 (TT genotype) was also reported to be associated with CAD in Chinese and south Indian populations [27,105]. The rs2168518 mutation (Figure 2C) decreases Mir-4513 activity [119]. The rs2168518 is associated with blood pressure, total lipids, total cholesterol, low-density lipoprotein cholesterol (LDL-C) and blood glucose [105,119]. Targets of miR-4513 include PCSK1, BNC2, MTMR3, $A N K 3$, and GOSR2 [119]. The rs2168518 polymorphism may affect the glucose and lipid homeostasis through regulation of these its targets [119]. PCSK1 genetic variation has been associated with insulin sensitivity and obesity [120]. The BNC2 gene is associated with $\mathrm{HbA} 1 \mathrm{c}$ and type 1 diabetes and is involved in the regulation of cholesterol metabolism [119]. The MTMR3 gene is involved in LDL-C metabolism, while the ANK3 gene is associated with higher systolic blood pressure [119]. GOSR2 is associated with hypertension, CAD and myocardial infarction (MI) [119,121,122].

\subsection{The Pre-MiR-27a rs895819 A>T}

The rs895819 (GG genotype) has been associated with myocardial infarction in the Chinese Han population [5]. It has been reported that the GG genotype of rs895819 polymorphism (Figure 2D) is associated with reduced high-density lipoprotein cholesterol (HDL-C) levels, while the AG and AA genotypes are associated with elevated HDL-C levels [5]. MiR-27a was reported to regulate lipid metabolism by inhibition of several lipid metabolic genes such as fatty acid synthase (FASN), sterol regulatory element-binding proteins 1 and 2 (SREBP-1,2), peroxisome proliferator-activated receptor alpha and gamma (PPAR $\alpha$ and $\gamma$ ), and apolipoprotein A1, B100 and E3 [123]. Moreover, MIR-27 also regulates lipid metabolism by decreasing lipogenesis and increasing the cellular secretion of lipids [123].

\subsection{MiR-146a rs2910164 G>C}

It was reported that the rs2910164 was associated with the risk to acute coronary syndrome (ACS) and CAD in Chinese, South African Indian and Korean populations respectively [100,124-126]. MIR146a polymorphism has been associated with total cholesterol, total lipids and C- reactive protein levels [124]. Moreover, it has been reported that miR-146a (with miR-155) regulates the pro-inflammatory NF-kappa B [59,60], and represses the MAP kinase pathway [127]. Furthermore, MIR146a was reported to be an important repressor of the inflammatory process [128]. It negatively regulates the production of proinflammatory cytokines TNF- $\alpha$, IL- $1 \beta$ and chemokines IL-8, and RANTES in macrophages induced by vesicular stomatitis virus [129]. The $C$ allele of (rs2910164G $>C$ ) reduces the expression of MIR146a [59], and decreases its anti-inflammation effects which may reduce the incidence of CAD. CAD is considered as a chronic inflammatory disease [130]. Jazdzewski et al., reported that in the C allele of the rs $2910164 \mathrm{G}>\mathrm{C}$, the expression of pre- and mature miR-146a would be less by up to 1.8-fold from $C$ allele compared with the $G$ allele [59]. Jazdzewski et al., suggested that rs2910164G $>C$ reduced 
expression of pre- and mature miR-146a [59]. The miR-146a is a NF-kappa B-dependent gene [59], and the role a NF-kappa B in atherosclerosis is well established [131]. It has been suggested that MIR146 decreased the activity of nuclear factor Kappa B in the toll-like receptor pathway by targeting the interleukin-1 receptor-associated kinase-1 (IRAK1) and TNF receptor associated factor-6 (TRAF6) [68]. The rs2910164 leads to reduced mature miR-146a which would increase the TNF- $\alpha$, IRAK1, and TRAF6 which may increase atherosclerotic related inflammatory response [132].

\section{6. $M i R-149$ rs $2292832 \mathrm{~T}>\mathrm{C}$}

The rs2292832 has been reported to be associated with CAD in Korean and Iranian populations [126,133]. This polymorphism is found in the precursor miR-149 and negatively affects its expression to mature miR-149 [126]. MiR-149 was reported to prevent mitochondrial related apoptosis through targeting the pro-apoptotic protein p53 upregulated modulator of apoptosis (Puma) [134]. Furthermore, knockdown of MIR149 renders the cardiomyocytes more sensitive to apoptotic stimulation, while MIR149 enforced expression enhances survival of cardiomyocytes [134]. In addition, miR-149 has been shown to be down-regulated in heart tissues with myocardial infarction (MI) from human and mouse [135]. Moreover, targets of miR-149 include genes of the inflammatory response [133]. For example, it has been reported that miR-149 targets the adaptor proteins MyD88 and negatively regulates the cytokine production stimulated by toll-like receptors [136]. Another SNP in miR-149 gene is the rs71428439 which was also been reported to be associated with MI [134], but Liu et al. reported that rs71428439 is not associated with the development of CVD [100].

\subsection{MIRLET7 Family of microRNA}

The Let-7 family of microRNA has been implicated in the maturation of metabolism of the cardiomyocytes [137]. It has been reported that the Let-7 family of microRNA is implicated in maturation, cell size and force contractibility of human embryonic stem cells [137]. It has been suggested that maturation of the cardiomyocytes induced by the Let-7 family resulted from the promotion of fatty acids metabolism and down-regulation of the insulin signaling pathway (phosphoinositide 3 kinase (PI3K)/AKT protein kinase) [137]. Therefore, gene variations in the Let-7 family represent plausible candidates for studying the functions of the Let-7 in cardiovascular disease (Table 2).

Table 2. Micro-RNA gene polymorphisms that have been associated with cardiovascular diseases in different populations.

\begin{tabular}{|c|c|c|c|c|c|}
\hline MiRNA & rs Number & Disease & $\begin{array}{c}\text { No. of } \\
\text { Control/Patients }\end{array}$ & Population & Ref \\
\hline 1-MiR-196a & rs11614913 & CVD & $834 / 920$ & Polish (With T2DM) & [37] \\
\hline \multirow{4}{*}{ 2-MiR-499 } & \multirow{4}{*}{ rs3746444 } & CAD & $-/ 1004$ & Chinese & \multirow{4}{*}[105,107,115,138]{} \\
\hline & & IS & Meta-analysis & Chinese & \\
\hline & & CAD & $480 / 435$ & Chinese & \\
\hline & & MI & $889 / 919$ & Chinese & \\
\hline 3-MiR-4513 & rs2168518 & CAD & $-/ 1004$ & Chinese & [105] \\
\hline 4-Pre-MiR-27a & rs895819 & MI & $287 / 646$ & $\begin{array}{c}\text { Chinese } \\
\text { Han population }\end{array}$ & [5] \\
\hline \multirow{3}{*}{ 5-Pre-MiR-146a } & \multirow{3}{*}{ rs2910164 } & ACS & $721 / 722$ & Chinese & \multirow{3}{*}[100,124,126,139]{} \\
\hline & & CAD & $535 / 522$ & Korean & \\
\hline & & CAD & $300 / 300$ & Iranian & \\
\hline 6-MiR-149 & rs2292832 & CAD & $535 / 522$ & Korean & [126] \\
\hline
\end{tabular}

Abbreviations: T2DM: Type 2 diabetic mellitus, CVD: cardiovascular disease, CAD: coronary artery disease, IS: ischemic stroke, MI: myocardial infarction, ACS, acute coronary syndrome. 


\section{Conclusions and Future Perspective}

MiRNAs are small RNA molecules that regulate the different vital cellular process. They silence the gene expression via efficient binding to their target mRNAs. Gene polymorphisms either in the miRNA target site or in the miRNAs can disrupt this binding which can contribute to the development of diseases such as cancer, diabetes and cardiovascular disease. For example, miR-124a rs531564, miR-146a rs2910164, miR-27a rs895819 and miR-34a rs72631823 have been associated with diabetes. Whereas, the miR-196a2 rs11614913, miR-499 rs3746444 and pre-miR-27a rs895819 have been associated with CVD. In order to study the role of miRNA gene polymorphisms in the development of diabetes, one may investigate the SNPs in miRNAs that are involved in pancreatic beta cells' proliferation (miR-375, miR-181a, miR-17, miR-24, miR-29a), survival and apoptosis (miR-577 and 200a/b/c, miR-34a) [140]. One may also consider the miRNAs which regulate the gene of elements of the insulin signaling pathway, for instance, the insulin receptor (MIR15b and MIR195), phosphoinositide 3-kinase (MIR320 and MIR378), and AKT (MIR143, and MIR106b) [140], or to investigate SNPs in miRNAs (e.g., microRNA147 [141]) that regulate genes important for an antidiabetes drug transporter such as SLC22A3 [142].

To study the roles of miRNA polymorphisms in the development of CVD, one may investigate the SNPs of the miRNAs that are involved in cardiac development [49] endothelial cell functions [50], and inflammatory response [143].

The result of GWASs have increased our understanding of drug metabolism, for instance, the SNPs that influence the warfarin metabolism have been identified and genetic testing for warfarin dosing can be performed in the clinic [144]. Moreover, GWASs revealed disease susceptibility loci that may help in identification, stratification and prognostication of individuals at disease risk [145-147]. There are still challenges facing the translation of genetic data to clinical practice in order to improve the prediction of disease risk loci. For instance, modern sequencing and statistical methods should be used in studies of gene-environment interactions with large cohorts to identify and characterize new SNPs relevant to T2DM prediction [146], and CVD. Most of the miRNA polymorphism studies have been conducted in Asian populations (Tables 1 and 2). These results should await clinical validation and detailed mechanistic exploration.

The miRNAs regulate many cellular processes, and there have been more than 2000 miRNAs discovered thus far. Therefore, the role of miRNA polymorphisms (if validated) may have a bright future in the fields of pharmacogenomics, molecular epidemiology, and personalized medicine.

Author Contributions: Conceptualization, I.E. and R.M.; Literature review, I.E.; Validation, all authors; Approval of the final version, all authors; Writing of the original draft, I.E.; Writing and Editing, I.E. and R.M.

Funding: This project received no external funding.

Conflicts of Interest: The authors declare no conflict of interest.

\section{References}

1. Starega-Roslan, J.; Krol, J.; Koscianska, E.; Kozlowski, P.; Szlachcic, W.J.; Sobczak, K.; Krzyzosiak, W.J. Structural basis of microrna length variety. Nucleic Acids Res. 2011, 39, 257-268. [CrossRef] [PubMed]

2. Filipowicz, W.; Bhattacharyya, S.N.; Sonenberg, N. Mechanisms of post-transcriptional regulation by micrornas: Are the answers in sight? Nat. Rev. Genet. 2008, 9, 102-114. [CrossRef] [PubMed]

3. Yu, A.M.; Tian, Y.; Tu, M.J.; Ho, P.Y.; Jilek, J.L. Microrna pharmacoepigenetics: Posttranscriptional regulation mechanisms behind variable drug disposition and strategy to develop more effective therapy. Drug Metab. Dispos. Biol. Fate Chem. 2016, 44, 308-319. [CrossRef] [PubMed]

4. Saunders, M.A.; Liang, H.; Li, W.H. Human polymorphism at micrornas and microrna target sites. Proc. Natl. Acad. Sci. USA 2007, 104, 3300-3305. [CrossRef] [PubMed]

5. Cai, M.Y.; Cheng, J.; Zhou, M.Y.; Liang, L.L.; Lian, S.M.; Xie, X.S.; Xu, S.; Liu, X.; Xiong, X.D. The association between pre-mir-27a rs895819 polymorphism and myocardial infarction risk in a chinese han population. Lipids Health Dis. 2018, 17, 7. [CrossRef] 
6. Ladomery, M.R.; Maddocks, D.G.; Wilson, I.D. Micrornas: Their discovery, biogenesis, function and potential use as biomarkers in non-invasive prenatal diagnostics. Int. J. Mol. Epidemiol. Genet. 2011, 2, 253-260.

7. Lee, Y.; Kim, M.; Han, J.; Yeom, K.H.; Lee, S.; Baek, S.H.; Kim, V.N. Microrna genes are transcribed by rna polymerase ii. EMBO J. 2004, 23, 4051-4060. [CrossRef]

8. Graves, P.; Zeng, Y. Biogenesis of mammalian micrornas: A global view. Genom. Proteom. Bioinform. 2012, 10, 239-245. [CrossRef]

9. Iwakawa, H.O.; Tomari, Y. The functions of micrornas: Mrna decay and translational repression. Trends Cell Biol. 2015, 25, 651-665. [CrossRef]

10. Romaine, S.P.; Tomaszewski, M.; Condorelli, G.; Samani, N.J. Micrornas in cardiovascular disease: An introduction for clinicians. Heart 2015, 101, 921-928. [CrossRef]

11. Curtis, H.J.; Sibley, C.R.; Wood, M.J. Mirtrons, an emerging class of atypical mirna. Wiley Interdiscip. Rev. RNA 2012, 3, 617-632. [CrossRef] [PubMed]

12. Cole, C.; Sobala, A.; Lu, C.; Thatcher, S.R.; Bowman, A.; Brown, J.W.; Green, P.J.; Barton, G.J.; Hutvagner, G. Filtering of deep sequencing data reveals the existence of abundant dicer-dependent small rnas derived from trnas. RNA 2009, 15, 2147-2160. [CrossRef] [PubMed]

13. Babiarz, J.E.; Hsu, R.; Melton, C.; Thomas, M.; Ullian, E.M.; Blelloch, R. A role for noncanonical micrornas in the mammalian brain revealed by phenotypic differences in dgcr8 versus dicer1 knockouts and small rna sequencing. RNA 2011, 17, 1489-1501. [CrossRef] [PubMed]

14. Catalanotto, C.; Cogoni, C.; Zardo, G. Microrna in control of gene expression: An overview of nuclear functions. Int. J. Mol. Sci. 2016, 17, 1712. [CrossRef] [PubMed]

15. Hu, W.; Coller, J. What comes first: Translational repression or mrna degradation? The deepening mystery of microrna function. Cell Res. 2012, 22, 1322-1324. [CrossRef]

16. Hammond, S.M. An overview of micrornas. Adv. Drug Deliv. Rev. 2015, 87, 3-14. [CrossRef]

17. Mishra, P.J.; Bertino, J.R. Microrna polymorphisms: The future of pharmacogenomics, molecular epidemiology and individualized medicine. Pharmacogenomics 2009, 10, 399-416. [CrossRef]

18. Hashimoto, Y.; Akiyama, Y.; Yuasa, Y. Multiple-to-multiple relationships between micrornas and target genes in gastric cancer. PLoS ONE 2013, 8, e62589. [CrossRef]

19. Shastry, B.S. Snps: Impact on gene function and phenotype. Methods Mol. Biol. 2009, 578, 3-22.

20. Casto, A.M.; Feldman, M.W. Genome-wide association study snps in the human genome diversity project populations: Does selection affect unlinked snps with shared trait associations? PLoS Genet. 2011, 7, e1001266. [CrossRef]

21. Elfaki, I.; Mir, R.; Almutairi, F.M.; Duhier, F.M.A. Cytochrome p450: Polymorphisms and roles in cancer, diabetes and atherosclerosis. Asian Pac. J. Cancer Prev. 2018, 19, 2057-2070. [PubMed]

22. Elfaki, I.; Almutairi, F.M.; Mir, R.; Khan, R.; Abu-Duhier, F. Cytochrome p450 cyp1b1*2 gene and its association with $\mathrm{t} 2 \mathrm{~d}$ in tabuk population, northwestern region of saudi arabia. Asian J. Pharm. Clin. Res. 2018, 11, 55-59. [CrossRef]

23. Elfaki, I.; Mir, R.; Abu-Duhier, F.M.; Khan, R.; Sakran, M. Phosphatidylinositol 3-kinase glu545lys and his1047tyr mutations are not associated with $\mathrm{t} 2 \mathrm{~d}$. Curr. Diabetes Rev. 2019. [CrossRef]

24. Almutairi, F.M.; Mir, R.; Abu-Duhier, F.; Khan, R.; Harby, K.; Elfaki, I. Slc2a2 gene (glucose transporter 2) variation is associated with an increased risk of developing $\mathrm{t} 2 \mathrm{~d}$ in an ethnic population of saudi arabia. Indian J. Public Health Res. Dev. 2019, 10, 600-605. [CrossRef]

25. Xue, A.; Wu, Y.; Zhu, Z.; Zhang, F.; Kemper, K.E.; Zheng, Z.; Yengo, L.; Lloyd-Jones, L.R.; Sidorenko, J.; $\mathrm{Wu}, \mathrm{Y}$; et al. Genome-wide association analyses identify 143 risk variants and putative regulatory mechanisms for type 2 diabetes. Nat. Commun. 2018, 9, 2941. [CrossRef]

26. Jha, C.K.; Mir, R.; Elfaki, I.; Javid, J.; Babakr, A.T.; Banu, S.; Chahal, S.M.S. Evaluation of the association of omentin $1 \mathrm{rs} 2274907 \mathrm{a}>\mathrm{t}$ and rs2274908 $\mathrm{g}>$ a gene polymorphisms with coronary artery disease in indian population: A case control study. J. Pers Med. 2019, 9, 30. [CrossRef]

27. Mir, R.; Jha, C.K.; Elfaki, I.; Javid, J.; Rehman, S.; Khullar, N.; Banu, S.; Chahal, S.M.S. Incidence of micror-4513c/t gene variability in coronary artery disease-A case-control study. Endocr. Metab. Immune Disord. Drug Targets 2019. [CrossRef]

28. Jha, C.; Mir, R.; Elfaki, I.; Banu, S. Ldlr Gene Polymorphisms (Rs5925 and Rs1529729) Are Associated with Susceptibility to Coronary Artery Disease in a South Indian Population. Med. Sci. 2019, 7, 80. [CrossRef] 
29. Mir, R.; Jha, C.K.; Elfaki, I.; Rehman, S.; Javid, J.; Khullar, N.; Banu, S.; Chahal, S.M.S. Microrna-224 (rs188519172 a $>\mathrm{g}$ ) gene variability is associated with a decreased susceptibility to coronary artery disease: A case-control study. MicroRNA 2018, 8, 198-205. [CrossRef]

30. Jha, C.K.; Mir, R.; Elfaki, I.; Khullar, N.; Rehman, S.; Javid, J.; Banu, S.; Chahal, S.M.S. Potential impact of microrna-423 gene variability in coronary artery disease. Endocr. Metab. Immune Disord. Drug Targets 2019, 19, 67-74. [CrossRef]

31. Jha, C.K.; Mir, R.; Banu, S.; Elfaki, I.; Chahal, S.M.S. Heterozosity in ldlr rs2228671 and ldlr rs72658855 are associated with increased risk of developing coronary artery disease in india-A case control study. Endocr. Metab. Immune Disord. Drug Targets 2019. [CrossRef]

32. Baulina, N.M.; Kulakova, O.G.; Favorova, O.O. Micrornas: The role in autoimmune inflammation. Acta Nat. 2016, 8, 21-33. [CrossRef]

33. Kwak, P.B.; Iwasaki, S.; Tomari, Y. The microrna pathway and cancer. Cancer Sci. 2010, 101, $2309-2315$. [CrossRef] [PubMed]

34. Nariman-Saleh-Fam, Z.; Bastami, M.; Somi, M.H.; Behjati, F.; Mansoori, Y.; Daraei, A.; Saadatian, Z.; Nariman-Saleh-Fam, L.; Mahmoodzadeh, H.; Makhdoumi, Y.; et al. Mirna-related polymorphisms in mir-423 (rs6505162) and pex6 (rs1129186) and risk of esophageal squamous cell carcinoma in an iranian cohort. Genet. Test. Mol. Biomark. 2017, 21, 382-390. [CrossRef] [PubMed]

35. Moszynska, A.; Gebert, M.; Collawn, J.F.; Bartoszewski, R. Snps in microrna target sites and their potential role in human disease. Open Biol. 2017, 7, 170019. [CrossRef]

36. Parvin, M.; Jahan, F.; Sarkar, P.K.; Howlader, Z.H.; Nabi, A.; Hosen, M.I. Functional polymorphism located in the microrna binding site of the insulin receptor (insr) gene confers risk for type 2 diabetes mellitus in the bangladeshi population. Biochem. Genet. 2019, 57, 20-33. [CrossRef]

37. Buraczynska, M.; Zukowski, P.; Wacinski, P.; Ksiazek, K.; Zaluska, W. Polymorphism in microrna-196a2 contributes to the risk of cardiovascular disease in type 2 diabetes patients. J. Diabetes Com. 2014, 28, 617-620. [CrossRef]

38. Shen, J.; Zhang, M.; Sun, M.; Tang, K.; Zhou, B. The relationship of mir-146a gene polymorphism with carotid atherosclerosis in chinese patients with type 2 diabetes mellitus. Thromb. Res. 2015, 136, 1149-1155. [CrossRef]

39. Wu, Y.F.; Xu, Q.; He, C.Y.; Li, Y.; Liu, J.W.; Deng, N.; Sun, L.P.; Yuan, Y. Association of polymorphisms in three pri-mirnas that target pepsinogen $c$ with the risk and prognosis of gastric cancer. Sci. Rep. 2017, 7, 39528. [CrossRef]

40. Rong, G.Q.; Zhang, X.M.; Chen, B.; Yang, X.D.; Wu, H.R.; Gong, W. Microrna gene polymorphisms and the risk of colorectal cancer. Oncol. Lett. 2017, 13, 3617-3623. [CrossRef]

41. Zhang, Y.; Bai, R.; Liu, C.; Ma, C.; Chen, X.; Yang, J.; Sun, D. Microrna single-nucleotide polymorphisms and diabetes mellitus: A comprehensive review. Clin. Genet. 2019, 95, 451-461. [CrossRef]

42. LaPierre, M.P.; Stoffel, M. Micrornas as stress regulators in pancreatic beta cells and diabetes. Mol. Metab. 2017, 6, 1010-1023. [CrossRef] [PubMed]

43. Poy, M.N.; Eliasson, L.; Krutzfeldt, J.; Kuwajima, S.; Ma, X.; Macdonald, P.E.; Pfeffer, S.; Tuschl, T.; Rajewsky, N.; Rorsman, P.; et al. A pancreatic islet-specific microrna regulates insulin secretion. Nature 2004, 432, 226-230. [CrossRef] [PubMed]

44. Baroukh, N.N.; Van Obberghen, E. Function of microrna-375 and microrna-124a in pancreas and brain. FEBS J. 2009, 276, 6509-6521. [CrossRef] [PubMed]

45. Frost, R.J.; Olson, E.N. Control of glucose homeostasis and insulin sensitivity by the let-7 family of micrornas. Proc. Natl. Acad. Sci. USA 2011, 108, 21075-21080. [CrossRef]

46. Cerf, M.E. Beta cell dysfunction and insulin resistance. Front. Endocrinol. (Lausanne) 2013, 4, 37. [CrossRef]

47. Massart, J.; Sjogren, R.J.O.; Lundell, L.S.; Mudry, J.M.; Franck, N.; O'Gorman, D.J.; Egan, B.; Zierath, J.R.; Krook, A. Altered mir-29 expression in type 2 diabetes influences glucose and lipid metabolism in skeletal muscle. Diabetes 2017, 66, 1807-1818. [CrossRef]

48. Guglielmi, V.; D’Adamo, M.; Menghini, R.; Cardellini, M.; Gentileschi, P.; Federici, M.; Sbraccia, P. Microrna 21 is up-regulated in adipose tissue of obese diabetic subjects. Nutr. Healthy Aging 2017, 4, 141-145. [CrossRef]

49. Tian, J.; An, X.; Niu, L. Role of micrornas in cardiac development and disease. Exp. Ther. Med. 2017, 13, 3-8. [CrossRef] 
50. Fernandez-Hernando, C.; Suarez, Y. Micrornas in endothelial cell homeostasis and vascular disease. Curr. Opin. Hematol. 2018, 25, 227-236. [CrossRef]

51. Yang, L.; Wang, B.; Zhou, Q.; Wang, Y.; Liu, X.; Liu, Z.; Zhan, Z. Microrna-21 prevents excessive inflammation and cardiac dysfunction after myocardial infarction through targeting kbtbd7. Cell Death Dis. 2018, 9, 769. [CrossRef]

52. Ge, Z.W.; Zhu, X.L.; Wang, B.C.; Hu, J.L.; Sun, J.J.; Wang, S.; Chen, X.J.; Meng, S.P.; Liu, L.; Cheng, Z.Y. Microrna-26b relieves inflammatory response and myocardial remodeling of mice with myocardial infarction by suppression of mapk pathway through binding to ptgs2. Int. J. Cardiol. 2019, 280, 152-159. [CrossRef] [PubMed]

53. Sethupathy, P.; Collins, F.S. Microrna target site polymorphisms and human disease. Trends Genet. TIG 2008, 24, 489-497. [CrossRef] [PubMed]

54. Li, Y.; Zhang, Y.; Li, X.; Shi, L.; Tao, W.; Shi, L.; Yang, M.; Wang, X.; Yang, Y.; Yao, Y. Association study of polymorphisms in mirnas with $\mathrm{t} 2 \mathrm{dm}$ in chinese population. Int. J. Med. Sci. 2015, 12, 875-880. [CrossRef] [PubMed]

55. Ciccacci, C.; Di Fusco, D.; Cacciotti, L.; Morganti, R.; D’Amato, C.; Greco, C.; Rufini, S.; Novelli, G.; Sangiuolo, F.; Spallone, V.; et al. Microrna genetic variations: Association with type 2 diabetes. Acta Diabetol. 2013, 50, 867-872. [CrossRef] [PubMed]

56. Sebastiani, G.; Po, A.; Miele, E.; Ventriglia, G.; Ceccarelli, E.; Bugliani, M.; Marselli, L.; Marchetti, P.; Gulino, A.; Ferretti, E.; et al. Microrna-124a is hyperexpressed in type 2 diabetic human pancreatic islets and negatively regulates insulin secretion. Acta Diabetol. 2015, 52, 523-530. [CrossRef] [PubMed]

57. Hashimoto, N.; Tanaka, T. Role of mirnas in the pathogenesis and susceptibility of diabetes mellitus. J. Hum. Genet. 2017, 62, 141-150. [CrossRef]

58. Erener, S.; Mojibian, M.; Fox, J.K.; Denroche, H.C.; Kieffer, T.J. Circulating mir-375 as a biomarker of beta-cell death and diabetes in mice. Endocrinology 2013, 154, 603-608. [CrossRef]

59. Jazdzewski, K.; Murray, E.L.; Franssila, K.; Jarzab, B.; Schoenberg, D.R.; de la Chapelle, A. Common snp in pre-mir-146a decreases mature mir expression and predisposes to papillary thyroid carcinoma. Proc. Natl. Acad. Sci. USA 2008, 105, 7269-7274. [CrossRef]

60. Mann, M.; Mehta, A.; Zhao, J.L.; Lee, K.; Marinov, G.K.; Garcia-Flores, Y.; Baltimore, D. An nf-kappab-microrna regulatory network tunes macrophage inflammatory responses. Nat. Commun. 2017, 8, 851. [CrossRef]

61. Patel, S.; Santani, D. Role of nf-kappa b in the pathogenesis of diabetes and its associated complications. Pharmacol. Rep. Pr. 2009, 61, 595-603. [CrossRef]

62. Ndisang, J.F. Role of heme oxygenase in inflammation, insulin-signalling, diabetes and obesity. Mediat. Inflamm. 2010, 2010, 359732. [CrossRef] [PubMed]

63. Suryavanshi, S.V.; Kulkarni, Y.A. Nf-kappabeta: A potential target in the management of vascular complications of diabetes. Front. Pharmacol. 2017, 8, 798. [CrossRef] [PubMed]

64. Lovis, P.; Roggli, E.; Laybutt, D.R.; Gattesco, S.; Yang, J.Y.; Widmann, C.; Abderrahmani, A.; Regazzi, R. Alterations in microrna expression contribute to fatty acid-induced pancreatic beta-cell dysfunction. Diabetes 2008, 57, 2728-2736. [CrossRef] [PubMed]

65. Kaidonis, G.; Gillies, M.C.; Abhary, S.; Liu, E.; Essex, R.W.; Chang, J.H.; Pal, B.; Sivaprasad, S.; Pefkianaki, M.; Daniell, M.; et al. A single-nucleotide polymorphism in the microrna-146a gene is associated with diabetic nephropathy and sight-threatening diabetic retinopathy in caucasian patients. Acta Diabetol. 2016, 53, 643-650. [CrossRef] [PubMed]

66. Assmann, T.S.; Duarte, G.C.K.; Brondani, L.A.; de Freitas, P.H.O.; Martins, E.M.; Canani, L.H.; Crispim, D. Polymorphisms in genes encoding mir-155 and mir-146a are associated with protection to type 1 diabetes mellitus. Acta Diabetol. 2017, 54, 433-441. [CrossRef]

67. Ciccacci, C.; Morganti, R.; Di Fusco, D.; D'Amato, C.; Cacciotti, L.; Greco, C.; Rufini, S.; Novelli, G.; Sangiuolo, F.; Marfia, G.A.; et al. Common polymorphisms in mir146a, mir128a and mir27a genes contribute to neuropathy susceptibility in type 2 diabetes. Acta Diabetol. 2014, 51, 663-671. [CrossRef]

68. Abo-Elmatty, D.M.; Mehanna, E.T. Mir146a rs2910164 (g/c) polymorphism is associated with incidence of preeclampsia in gestational diabetes patients. Biochem. Genet. 2019, 57, 222-233. [CrossRef]

69. Dziedzic, M.; Powrozek, T.; Orlowska, E.; Koch, W.; Kukula-Koch, W.; Gawel, K.; Bednarek-Skublewska, A.; Malecka-Massalska, T.; Milanowski, J.; Petkowicz, B.; et al. Relationship between microrna-146a expression and plasma renalase levels in hemodialyzed patients. PLoS ONE 2017, 12, e0179218. [CrossRef] 
70. Desir, G.V. Role of renalase in the regulation of blood pressure and the renal dopamine system. Curr. Opin. Nephrol. Hypertens. 2011, 20, 31-36. [CrossRef]

71. Ghaedi, H.; Tabasinezhad, M.; Alipoor, B.; Shokri, F.; Movafagh, A.; Mirfakhraie, R.; Omrani, M.D.; Masotti, A. The pre-mir-27a variant rs895819 may contribute to type 2 diabetes mellitus susceptibility in an iranian cohort. J. Endocrinol. Investig. 2016, 39, 1187-1193. [CrossRef]

72. Offer, S.M.; Butterfield, G.L.; Jerde, C.R.; Fossum, C.C.; Wegner, N.J.; Diasio, R.B. Micrornas mir-27a and mir-27b directly regulate liver dihydropyrimidine dehydrogenase expression through two conserved binding sites. Mol. Cancer Ther. 2014, 13, 742-751. [CrossRef] [PubMed]

73. Sun, Q.; Gu, H.; Zeng, Y.; Xia, Y.; Wang, Y.; Jing, Y.; Yang, L.; Wang, B. Hsa-mir-27a genetic variant contributes to gastric cancer susceptibility through affecting mir-27a and target gene expression. Cancer Sci. 2010, 101, 2241-2247. [CrossRef]

74. Qin, L.; Chen, Y.; Niu, Y.; Chen, W.; Wang, Q.; Xiao, S.; Li, A.; Xie, Y.; Li, J.; Zhao, X.; et al. A deep investigation into the adipogenesis mechanism: Profile of micrornas regulating adipogenesis by modulating the canonical wnt/beta-catenin signaling pathway. BMC Genom. 2010, 11, 320. [CrossRef] [PubMed]

75. Kim, S.Y.; Kim, A.Y.; Lee, H.W.; Son, Y.H.; Lee, G.Y.; Lee, J.W.; Lee, Y.S.; Kim, J.B. Mir-27a is a negative regulator of adipocyte differentiation via suppressing ppargamma expression. Biochem. Biophys. Res. Commun. 2010, 392, 323-328. [CrossRef] [PubMed]

76. Ye, J. Mechanisms of insulin resistance in obesity. Front. Med. 2013, 7, 14-24. [CrossRef] [PubMed]

77. Wang, T.T.; Chen, Y.J.; Sun, L.L.; Zhang, S.J.; Zhou, Z.Y.; Qiao, H. Affection of single-nucleotide polymorphisms in mir-27a, mir-124a, and mir-146a on susceptibility to type 2 diabetes mellitus in chinese han people. Chin. Med. J. 2015, 128, 533-539. [CrossRef]

78. Locke, J.M.; Lango Allen, H.; Harries, L.W. A rare snp in pre-mir-34a is associated with increased levels of mir-34a in pancreatic beta cells. Acta Diabetol. 2014, 51, 325-329. [CrossRef]

79. Regazzi, R.; Sadoul, K.; Meda, P.; Kelly, R.B.; Halban, P.A.; Wollheim, C.B. Mutational analysis of vamp domains implicated in ca2+-induced insulin exocytosis. EMBO J. 1996, 15, 6951-6959. [CrossRef]

80. Hastoy, B.; Scotti, P.A.; Milochau, A.; Fezoua-Boubegtiten, Z.; Rodas, J.; Megret, R.; Desbat, B.; Laguerre, M.; Castano, S.; Perrais, D.; et al. A central small amino acid in the vamp2 transmembrane domain regulates the fusion pore in exocytosis. Sci. Rep. 2017, 7, 2835. [CrossRef]

81. Roggli, E.; Gattesco, S.; Caille, D.; Briet, C.; Boitard, C.; Meda, P.; Regazzi, R. Changes in microrna expression contribute to pancreatic beta-cell dysfunction in prediabetic nod mice. Diabetes 2012,61,1742-1751. [CrossRef]

82. Zhou, J.; Peng, R.; Li, T.; Luo, X.; Peng, H.; Zha, H.; Yin, P.; Wen, L.; Zhang, Z. A potentially functional polymorphism in the regulatory region of let-7a-2 is associated with an increased risk for diabetic nephropathy. Gene 2013, 527, 456-461. [CrossRef] [PubMed]

83. Sanchez, A.P.; Sharma, K. Transcription factors in the pathogenesis of diabetic nephropathy. Expert Rev. Mol. Med. 2009, 11, e13. [CrossRef] [PubMed]

84. Faraoni, I.; Antonetti, F.R.; Cardone, J.; Bonmassar, E. Mir-155 gene: A typical multifunctional microrna. Biochim. Biophys. Acta 2009, 1792, 497-505. [CrossRef] [PubMed]

85. Ma, X.; Becker Buscaglia, L.E.; Barker, J.R.; Li, Y. Micrornas in nf-kappab signaling. J. Mol. Cell Biol. 2011, 3, 159-166. [CrossRef] [PubMed]

86. Caruso, M.; Ma, D.; Msallaty, Z.; Lewis, M.; Seyoum, B.; Al-janabi, W.; Diamond, M.; Abou-Samra, A.B.; Hojlund, K.; Tagett, R.; et al. Increased interaction with insulin receptor substrate 1, a novel abnormality in insulin resistance and type 2 diabetes. Diabetes 2014, 63, 1933-1947. [CrossRef] [PubMed]

87. Derosa, G.; Maffioli, P. Peroxisome proliferator-activated receptor-gamma (ppar-gamma) agonists on glycemic control, lipid profile and cardiovascular risk. Curr Mol. Pharm. 2012, 5, 272-281. [CrossRef]

88. Wu, B.; Liu, G.; He, F.; Liu, R.; Wang, Z.; Wang, Y.; Zhou, H.; Zhang, W. Mir-3188 (rs7247237-c>t) single-nucleotide polymorphism is associated with the incidence of vascular complications in chinese patients with type 2 diabetes. J. Cardiovasc. Pharmacol. 2019, 74, 62-70. [CrossRef]

89. Sharma, A.; Sellers, S.; Stefanovic, N.; Leung, C.; Tan, S.M.; Huet, O.; Granville, D.J.; Cooper, M.E.; de Haan, J.B.; Bernatchez, P. Direct endothelial nitric oxide synthase activation provides atheroprotection in diabetes-accelerated atherosclerosis. Diabetes 2015, 64, 3937-3950. [CrossRef]

90. Wang, C.; Liu, E.; Li, W.; Cui, J.; Li, T. Mir-3188 inhibits non-small cell lung cancer cell proliferation through foxo1-mediated mtor-p-pi3k/akt-c-jun signaling pathway. Front. Pharmacol. 2018, 9, 1362. [CrossRef] 
91. Huang, X.; Liu, G.; Guo, J.; Su, Z. The pi3k/akt pathway in obesity and type 2 diabetes. Int. J. Biol. Sci. 2018, 14, 1483-1496. [CrossRef]

92. McAuley, A.K.; Dirani, M.; Wang, J.J.; Connell, P.P.; Lamoureux, E.L.; Hewitt, A.W. A genetic variant regulating mir-126 is associated with sight threatening diabetic retinopathy. Diabetes Vasc. Dis. Res. 2015, 12, 133-138. [CrossRef] [PubMed]

93. Fish, J.E.; Santoro, M.M.; Morton, S.U.; Yu, S.; Yeh, R.F.; Wythe, J.D.; Ivey, K.N.; Bruneau, B.G.; Stainier, D.Y.; Srivastava, D. Mir-126 regulates angiogenic signaling and vascular integrity. Dev. Cell 2008, 15, 272-284. [CrossRef] [PubMed]

94. Karaman, S.; Leppanen, V.M.; Alitalo, K. Vascular endothelial growth factor signaling in development and disease. Development 2018, 145. [CrossRef] [PubMed]

95. Xiang, Y.; Guo, J.; Peng, Y.F.; Tan, T.; Huang, H.T.; Luo, H.C.; Wei, Y.S. Association of mir-21, mir-126 and mir-605 gene polymorphisms with ischemic stroke risk. Oncotarget 2017, 8, 95755-95763. [CrossRef] [PubMed]

96. Sessa, R.; Seano, G.; di Blasio, L.; Gagliardi, P.A.; Isella, C.; Medico, E.; Cotelli, F.; Bussolino, F.; Primo, L. The mir-126 regulates angiopoietin-1 signaling and vessel maturation by targeting p85beta. Biochim. Biophys. Acta 2012, 1823, 1925-1935. [CrossRef]

97. Fragoso, J.M.; Ramirez-Bello, J.; Martinez-Rios, M.A.; Pena-Duque, M.A.; Posadas-Sanchez, R.; Delgadillo-Rodriguez, H.; Jimenez-Morales, M.; Posadas-Romero, C.; Vargas-Alarcon, G. Mir-196a2 (rs11614913) polymorphism is associated with coronary artery disease, but not with in-stent coronary restenosis. Inflamm. Res. J. Eur. Histamine Res. Soc. 2019, 68, 215-221. [CrossRef]

98. Hoffman, A.E.; Zheng, T.; Yi, C.; Leaderer, D.; Weidhaas, J.; Slack, F.; Zhang, Y.; Paranjape, T.; Zhu, Y. Microrna mir-196a-2 and breast cancer: A genetic and epigenetic association study and functional analysis. Cancer Res. 2009, 69, 5970-5977. [CrossRef]

99. Ross, R.L.; Burns, J.E.; Taylor, C.F.; Mellor, P.; Anderson, D.H.; Knowles, M.A. Identification of mutations in distinct regions of p85 alpha in urothelial cancer. PLoS ONE 2013, 8, e84411. [CrossRef]

100. Liu, X.; You, L.; Zhou, R.; Zhang, J. Significant association between functional microrna polymorphisms and coronary heart disease susceptibility: A comprehensive meta-analysis involving 16484 subjects. Oncotarget 2017, 8, 5692-5702. [CrossRef]

101. Pin, A.L.; Houle, F.; Fournier, P.; Guillonneau, M.; Paquet, E.R.; Simard, M.J.; Royal, I.; Huot, J. Annexin-1-mediated endothelial cell migration and angiogenesis are regulated by vascular endothelial growth factor (vegf)-induced inhibition of mir-196a expression. J. Biol. Chem. 2012, 287, 30541-30551. [CrossRef]

102. Purvis, G.S.D.; Chiazza, F.; Chen, J.; Azevedo-Loiola, R.; Martin, L.; Kusters, D.H.M.; Reutelingsperger, C.; Fountoulakis, N.; Gnudi, L.; Yaqoob, M.M.; et al. Annexin a1 attenuates microvascular complications through restoration of akt signalling in a murine model of type 1 diabetes. Diabetologia 2018, 61, 482-495. [CrossRef] [PubMed]

103. de Jong, R.; Leoni, G.; Drechsler, M.; Soehnlein, O. The advantageous role of annexin a1 in cardiovascular disease. Cell Adhes. Migr. 2017, 11, 261-274. [CrossRef] [PubMed]

104. Tousoulis, D.; Oikonomou, E.; Economou, E.K.; Crea, F.; Kaski, J.C. Inflammatory cytokines in atherosclerosis: Current therapeutic approaches. Eur. Heart J. 2016, 37, 1723-1732. [CrossRef] [PubMed]

105. Li, Q.; Chen, L.; Chen, D.; Wu, X.; Chen, M. Influence of microrna-related polymorphisms on clinical outcomes in coronary artery disease. Am. J. Transl. Res. 2015, 7, 393-400.

106. Fawzy, M.S.; Toraih, E.A.; Hamed, E.O.; Hussein, M.H.; Ismail, H.M. Association of mir-499a expression and seed region variant (rs3746444) with cardiovascular disease in egyptian patients. Acta Cardiol. 2018, 73, 131-140. [CrossRef]

107. Chen, W.; Shao, D.; Gu, H.; Gong, J.; Zhang, J. Hsa-mir-499 rs3746444 t/c polymorphism is associated with increased risk of coronary artery disease in a chinese population. Acta Cardiol. Sin. 2017, 33, 34-40.

108. Xin, Y.; Yang, C.; Han, Z. Circulating mir-499 as a potential biomarker for acute myocardial infarction. Ann. Transl. Med. 2016, 4, 135. [CrossRef]

109. Wilson, K.D.; Hu, S.; Venkatasubrahmanyam, S.; Fu, J.D.; Sun, N.; Abilez, O.J.; Baugh, J.J.; Jia, F.; Ghosh, Z.; Li, R.A.; et al. Dynamic microrna expression programs during cardiac differentiation of human embryonic stem cells: Role for mir-499. Circ. Cardiovasc. Genet. 2010, 3, 426-435. [CrossRef] 
110. Wang, J.; Jia, Z.; Zhang, C.; Sun, M.; Wang, W.; Chen, P.; Ma, K.; Zhang, Y.; Li, X.; Zhou, C. Mir-499 protects cardiomyocytes from $\mathrm{h}$ 2o 2-induced apoptosis via its effects on pdcd 4 and pacs2. RNA Biol. 2014, 11, 339-350. [CrossRef]

111. Hosoda, T.; Zheng, H.; Cabral-da-Silva, M.; Sanada, F.; Ide-Iwata, N.; Ogorek, B.; Ferreira-Martins, J.; Arranto, C.; D'Amario, D.; del Monte, F.; et al. Human cardiac stem cell differentiation is regulated by a mircrine mechanism. Circulation 2011, 123, 1287-1296. [CrossRef]

112. Hashemi, M.; Eskandari-Nasab, E.; Zakeri, Z.; Atabaki, M.; Bahari, G.; Jahantigh, M.; Taheri, M.; Ghavami, S. Association of pre-mirna-146a rs2910164 and premirna-499 rs3746444 polymorphisms and susceptibility to rheumatoid arthritis. Mol. Med. Rep. 2013, 7, 287-291. [CrossRef] [PubMed]

113. Wang, J.X.; Jiao, J.Q.; Li, Q.; Long, B.; Wang, K.; Liu, J.P.; Li, Y.R.; Li, P.F. Mir-499 regulates mitochondrial dynamics by targeting calcineurin and dynamin-related protein-1. Nat. Med. 2011, 17, 71-78. [CrossRef] [PubMed]

114. Yu, T.; Fox, R.J.; Burwell, L.S.; Yoon, Y. Regulation of mitochondrial fission and apoptosis by the mitochondrial outer membrane protein hfis1. J. Cell Sci. 2005, 118, 4141-4151. [CrossRef] [PubMed]

115. Li, C.X.; Weng, H.; Zheng, J.; Feng, Z.H.; Ou, J.L.; Liao, W.J. Association between micrornas polymorphisms and risk of ischemic stroke: A meta-analysis in chinese individuals. Front. Aging Neurosci. 2018, 10, 82. [CrossRef] [PubMed]

116. Madjid, M.; Willerson, J.T. Inflammatory markers in coronary heart disease. Br. Med. Bull. 2011, 100, $23-38$. [CrossRef]

117. Yang, X.; Li, X.; Zhou, B. A meta-analysis of mir-499 rs3746444 polymorphism for cancer risk of different systems: Evidence from 65 case-control studies. Front. Physiol. 2018, 9, 737. [CrossRef]

118. Wang, D.; Pan, G. Association of rs2910164 polymorphism in mirna-146 and rs3746444 polymorphism in mirna-499 with inflammatory arthritis: A meta-analysis. Biomed. Res. Int. 2019, 2019, 7305750. [CrossRef]

119. Ghanbari, M.; de Vries, P.S.; de Looper, H.; Peters, M.J.; Schurmann, C.; Yaghootkar, H.; Dorr, M.; Frayling, T.M.; Uitterlinden, A.G.; Hofman, A.; et al. A genetic variant in the seed region of mir-4513 shows pleiotropic effects on lipid and glucose homeostasis, blood pressure, and coronary artery disease. Hum. Mutat. 2014, 35, 1524-1531. [CrossRef]

120. Heni, M.; Haupt, A.; Schafer, S.A.; Ketterer, C.; Thamer, C.; Machicao, F.; Stefan, N.; Staiger, H.; Haring, H.U.; Fritsche, A. Association of obesity risk snps in pcsk1 with insulin sensitivity and proinsulin conversion. BMC Med. Genet. 2010, 11, 86. [CrossRef]

121. Pan, S.; Guan, G.C.; Lv, Y.; Liu, Z.W.; Liu, F.Q.; Zhang, Y.; Zhu, S.M.; Zhang, R.H.; Zhao, N.; Shi, S.; et al. G-t haplotype established by rs3785889-rs16941382 in gosr2 gene is associated with coronary artery disease in chinese han population. Oncotarget 2017, 8, 82165-82173. [CrossRef]

122. Pan, S.; Nakayama, T.; Sato, N.; Izumi, Y.; Soma, M.; Aoi, N.; Ma, Y.; Hinohara, S.; Doba, N. A haplotype of the gosr2 gene is associated with myocardial infarction in japanese men. Genet. Test. Mol. Biomark. 2013, 17, 481-488. [CrossRef] [PubMed]

123. Yang, Z.; Cappello, T.; Wang, L. Emerging role of micrornas in lipid metabolism. Acta Pharm. Sin. B 2015, 5, 145-150. [CrossRef] [PubMed]

124. Huang, S.; Lv, Z.; Deng, Q.; Li, L.; Yang, B.; Feng, J.; Wu, T.; Zhang, X.; Cheng, J. A genetic variant in pre-mir-146a (rs2910164 c>g) is associated with the decreased risk of acute coronary syndrome in a chinese population. Tohoku J. Exp. Med. 2015, 237, 227-233. [CrossRef] [PubMed]

125. Ramkaran, P.; Khan, S.; Phulukdaree, A.; Moodley, D.; Chuturgoon, A.A. Mir-146a polymorphism influences levels of mir-146a, irak-1, and traf-6 in young patients with coronary artery disease. Cell Biochem. Biophys. 2014, 68, 259-266. [CrossRef] [PubMed]

126. Sung, J.H.; Kim, S.H.; Yang, W.I.; Kim, W.J.; Moon, J.Y.; Kim, I.J.; Cha, D.H.; Cho, S.Y.; Kim, J.O.; Kim, K.A.; et al. Mirna polymorphisms (mir146a, mir149, mir196a2 and mir499) are associated with the risk of coronary artery disease. Mol. Med. Rep. 2016, 14, 2328-2342. [CrossRef] [PubMed]

127. Cheng, H.S.; Sivachandran, N.; Lau, A.; Boudreau, E.; Zhao, J.L.; Baltimore, D.; Delgado-Olguin, P.; Cybulsky, M.I.; Fish, J.E. Microrna-146 represses endothelial activation by inhibiting pro-inflammatory pathways. Embo Mol. Med. 2013, 5, 1017-1034. [CrossRef]

128. Saba, R.; Sorensen, D.L.; Booth, S.A. Microrna-146a: A dominant, negative regulator of the innate immune response. Front. Immunol. 2014, 5, 578. [CrossRef] 
129. Hou, J.; Wang, P.; Lin, L.; Liu, X.; Ma, F.; An, H.; Wang, Z.; Cao, X. Microrna-146a feedback inhibits rig-i-dependent type i ifn production in macrophages by targeting traf6, irak1, and irak2. J. Immunol. 2009, 183, 2150-2158. [CrossRef]

130. Fioranelli, M.; Bottaccioli, A.G.; Bottaccioli, F.; Bianchi, M.; Rovesti, M.; Roccia, M.G. Stress and inflammation in coronary artery disease: A review psychoneuroendocrineimmunology-based. Front. Immunol. 2018, 9, 2031. [CrossRef]

131. Pamukcu, B.; Lip, G.Y.; Shantsila, E. The nuclear factor-kappa b pathway in atherosclerosis: A potential therapeutic target for atherothrombotic vascular disease. Thromb. Res. 2011, 128, 117-123. [CrossRef]

132. Qu, J.Y.; Xi, J.; Zhang, Y.H.; Zhang, C.N.; Song, L.; Song, Y.; Hui, R.T.; Chen, J.Z. Association of the microrna-146a snp rs2910164 with ischemic stroke incidence and prognosis in a chinese population. Int. J. Mol. Sci. 2016, 17, 660. [CrossRef] [PubMed]

133. Ghaffarzadeh, M.; Ghaedi, H.; Alipoor, B.; Omrani, M.D.; Kazerouni, F.; Shanaki, M.; Labbaf, A.; Pashaiefar, H.; Rahimipour, A. Association of mir-149 (rs2292832) variant with the risk of coronary artery disease. J. Med. Biochem. 2017, 36, 251-258. [CrossRef] [PubMed]

134. Ding, S.L.; Wang, J.X.; Jiao, J.Q.; Tu, X.; Wang, Q.; Liu, F.; Li, Q.; Gao, J.; Zhou, Q.Y.; Gu, D.F.; et al. A pre-microrna-149 (mir-149) genetic variation affects mir-149 maturation and its ability to regulate the puma protein in apoptosis. J. Biol. Chem. 2013, 288, 26865-26877. [CrossRef] [PubMed]

135. van Rooij, E.; Sutherland, L.B.; Thatcher, J.E.; DiMaio, J.M.; Naseem, R.H.; Marshall, W.S.; Hill, J.A.; Olson, E.N. Dysregulation of micrornas after myocardial infarction reveals a role of mir-29 in cardiac fibrosis. Proc. Natl. Acad. Sci. USA 2008, 105, 13027-13032. [CrossRef]

136. Xu, G.; Zhang, Z.; Xing, Y.; Wei, J.; Ge, Z.; Liu, X.; Zhang, Y.; Huang, X. Microrna-149 negatively regulates tlr-triggered inflammatory response in macrophages by targeting myd88. J. Cell Biochem. 2014, 115, 919-927. [CrossRef]

137. Kuppusamy, K.T.; Jones, D.C.; Sperber, H.; Madan, A.; Fischer, K.A.; Rodriguez, M.L.; Pabon, L.; Zhu, W.Z.; Tulloch, N.L.; Yang, X.; et al. Let-7 family of microrna is required for maturation and adult-like metabolism in stem cell-derived cardiomyocytes. Proc. Natl. Acad. Sci. USA 2015, 112, 2785-2794. [CrossRef]

138. Chen, C.; Hong, H.; Chen, L.; Shi, X.; Chen, Y.; Weng, Q. Association of microrna polymorphisms with the risk of myocardial infarction in a chinese population. Tohoku J. Exp. Med. 2014, 233, 89-94. [CrossRef]

139. Bastami, M.; Ghaderian, S.M.; Omrani, M.D.; Mirfakhraie, R.; Vakili, H.; Parsa, S.A.; Nariman-Saleh-Fam, Z.; Masotti, A. Mirna-related polymorphisms in mir-146a and tcf21 are associated with increased susceptibility to coronary artery disease in an iranian population. Genet. Test. Mol. Biomark. 2016, 20, 241-248. [CrossRef]

140. Feng, J.; Xing, W.; Xie, L. Regulatory roles of micrornas in diabetes. Int. J. Mol. Sci. 2016, 17, 1729. [CrossRef] [PubMed]

141. Moeez, S.; Riaz, S.; Masood, N.; Kanwal, N.; Arif, M.A.; Niazi, R.; Khalid, S. Evaluation of the rs3088442 g > a slc22a3 gene polymorphism and the role of microrna 147 in groups of adult pakistani populations with type 2 diabetes in response to metformin. Can. J. Diabetes 2019, 43, 128-135. [CrossRef]

142. Chen, L.; Hong, C.; Chen, E.C.; Yee, S.W.; Xu, L.; Almof, E.U.; Wen, C.; Fujii, K.; Johns, S.J.; Stryke, D.; et al. Genetic and epigenetic regulation of the organic cation transporter 3, slc22a3. Pharm. J. 2013, 13, 110-120.

143. O'Connell, R.M.; Rao, D.S.; Baltimore, D. Microrna regulation of inflammatory responses. Annu. Rev. Immunol. 2012, 30, 295-312. [CrossRef] [PubMed]

144. Bush, W.S.; Moore, J.H. Chapter 11: Genome-wide association studies. PLoS Comput. Biol. 2012, 8, e1002822. [CrossRef] [PubMed]

145. Chatterjee, N.; Shi, J.; Garcia-Closas, M. Developing and evaluating polygenic risk prediction models for stratified disease prevention. Nat. Rev. Genet. 2016, 17, 392-406. [CrossRef]

146. Lyssenko, V.; Laakso, M. Genetic screening for the risk of type 2 diabetes: Worthless or valuable? Diabetes Care 2013, 36 (Suppl. 2), S120-S126. [CrossRef] [PubMed]

147. Knowles, J.W.; Ashley, E.A. Cardiovascular disease: The rise of the genetic risk score. PLoS Med. 2018, 15, e1002546. [CrossRef]

(C) 2019 by the authors. Licensee MDPI, Basel, Switzerland. This article is an open access article distributed under the terms and conditions of the Creative Commons Attribution (CC BY) license (http://creativecommons.org/licenses/by/4.0/). 